\title{
New Lycopodium alkaloids from Lycopodium obscurum
}

\author{
Xue-Yuan Zhang, ${ }^{\text {a,b }}$ Liao-Bin Dong, ${ }^{\text {a,b }}$ Fei Liu, ${ }^{\text {a,b }}$ Xing-De Wu, ${ }^{a}$ Juan He, ${ }^{a}$ Li-Yan Peng, ${ }^{\text {a Huai-Rong }}$ \\ LuO, ${ }^{\mathrm{a}}$ and Qin-Shi ZHAO ${ }^{\mathrm{a}, *}$
}

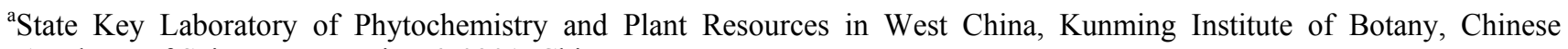
Academy of Sciences, Kunming 650201, China

${ }^{b}$ University of Chinese Academy of Sciences, Beijing 100049, China

Received 19 February 2013; Accepted 17 March 2013

(C) The Author(s) 2013. This article is published with open access at Springerlink.com

\begin{abstract}
Three new Lycopodium alkaloids, obscurumines C-E (1-3), along with nine known compounds, were isolated from the club moss Lycopodium obscurum L. Structures of the new compounds were determined on the basis of their spectroscopic analysis and the relative configurations of $\mathbf{1}$ were established by X-ray crystallographic analysis. All the new isolates were tested for the acetylcholinesterase (AChE) inhibitory activity.
\end{abstract}

Keywords: obscurumines, Lydopodium alkaloids, Lycopodium obscurum, acetylcholinesterase (AChE) inhibitory activity

\section{Introduction}

The Lycopodium alkaloids represent a large family of plant secondary metabolites obtained from the club moss belonging to Lycopodiaceae. ${ }^{1,2}$ Since the impressively diverse skeletons and interesting biological activities, these alkaloids continue to be of interest from a biogenetic and biological point of view and some of them have been challenging targets for total synthesis. $^{3-5}$ Lycopodium obscurum L., one of the club moss, has been used in China as a traditional folk medicine for the treatment of contusion, dysmenorrhea, quadriplegia, and arthritic pain. ${ }^{6,7}$ Previously phytochemical investigation indicated triterpenoids were the main compounds of this plant and only few Lycopodium alkaloids were isolated. ${ }^{8-10}$ As part of an ongoing program aimed at discovering structurally interesting and bioactive Lycopodium alkaloids, ${ }^{11,12}$ three new Lycopodium alkaloids, obscurumines C-E (1-3), along with nine known compounds, were isolated from the whole herb of $L$. obscurum L. Herein, we report the isolation, structure elucidation, and acetylcholinesterase (AChE) inhibitory activity of the new isolates.

\section{Results and Discussion}

The alkaloidal extract of $L$. obscurum was separated by normal-phase silica gel, RP-18 silica gel, HPLC, and Sephadex LH-20 chromatography to afford three new Lycopodium alkaloids, obscurumines C-E (1-3), along with nine known compounds. The structures of known compounds, compared with literatures data, were identified as lycopodine, ${ }^{13}$ anhydrolycodoline, ${ }^{14}$ obscurinine, ${ }^{9}$ obscurinine $\mathrm{B},{ }^{8}$ lycoflex-

*To whom correspondence should be addressed. E-mail: qinshizhao@mail.kib.ac.cn

\section{黑 Springer}

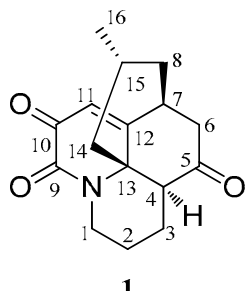

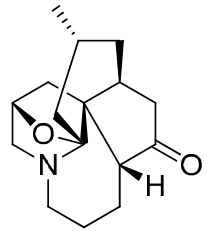

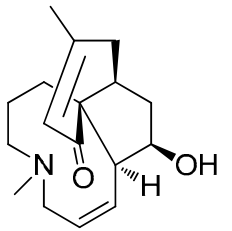

3
Figure 1. Chemical structure of isolated compounds 1-3

ine, ${ }^{15}$ acetyldihydrolycopodine, ${ }^{16}(+)$-acetylfawcettiine, ${ }^{17} \mathrm{~N}$ demethyl- $\alpha$-obscurine, ${ }^{18} N$-demethyl- $\beta$-obscurine. ${ }^{19}$

Obscurumine $\mathrm{C}(\mathbf{1})$, colorless crystals, has a molecular formula $\mathrm{C}_{16} \mathrm{H}_{19} \mathrm{NO}_{3}$ as established by HREIMS at $\mathrm{m} / \mathrm{z}$ $273.1359\left[\mathrm{M}^{+}\right]$(calc. 273.1365), indicating eight degrees of unsaturation. The IR absorptions at 1710,1685 , and $1658 \mathrm{~cm}^{-1}$ implied the presence of carbonyl groups. Analysis of the ${ }^{1} \mathrm{H}$ and ${ }^{13} \mathrm{C}$ NMR spectra of 1 (Table 1 ) revealed 16 carbon signals due to five quaternary carbons (three ketone carbons, one olefinic carbon, and one $s p^{3}$ quaternary carbon), four methine groups (one olefinic carbon), six methylene groups, and one methyl group $\left(\delta_{\mathrm{H}} 0.71, \mathrm{~d}, J=5.9 \mathrm{~Hz}\right)$. The ${ }^{1} \mathrm{H}-{ }^{1} \mathrm{H}$ COSY correlations revealed the existence of two fragments, a $(\mathrm{C}$ 1-C-4) and b (C-6-C-8, C-8/C15/C-14, C-15-C-16), as shown in Figure 2. In the HMBC spectrum, the correlations of the proton $\left(\delta_{\mathrm{H}} 2.42, \mathrm{H}-4\right)$ at the terminal carbon $(\mathrm{C}-4)$ of fragment a and the protons $\left(\delta_{\mathrm{H}} 2.71,2.39, \mathrm{H}-6\right)$ at the terminal carbon (C-6) of fragment $\mathbf{b}$ with the carbonyl carbon $\left(\mathrm{C}-5, \delta_{\mathrm{C}} 205.7\right)$ indicated the connection of C-4/C-5/C-6. While, the connection of $\mathrm{C}-4 / \mathrm{C}-13 / \mathrm{C}-14$ were derived from HMBC cross-peaks of $\mathrm{H}-4$ and $\mathrm{H}-14$ to $\mathrm{C}-13$. Meanwhile, the HMBC correlations of H-1 with C-9 and C-13 established the connections of C-1, 
Table $1 .{ }^{1} \mathrm{H}$ and ${ }^{13} \mathrm{C}$ NMR data for $1-3(\delta$ in ppm and $J$ in $\mathrm{Hz})$

\begin{tabular}{|c|c|c|c|c|c|c|}
\hline \multirow[b]{2}{*}{ No. } & \multicolumn{2}{|r|}{$1^{\mathrm{a}}$} & \multicolumn{2}{|r|}{$2^{\mathrm{b}}$} & \multicolumn{2}{|r|}{$3^{\mathrm{c}}$} \\
\hline & $\delta_{\mathrm{C}}$ & $\delta_{\mathrm{H}}$ & $\delta_{\mathrm{C}}$ & $\delta_{\mathrm{H}}$ & $\delta_{\mathrm{C}}$ & $\delta_{\mathrm{H}}$ \\
\hline 1a & $36.6 \mathrm{CH}_{2}$ & $4.51(\mathrm{dd}, 13.8,3.9)$ & $41.9 \mathrm{CH}_{2}$ & $3.05(\mathrm{~m})$ & $52.4 \mathrm{CH}_{2}$ & $3.32(\mathrm{dd}, 13.5,7.9)$ \\
\hline $1 \mathrm{~b}$ & & $2.79(\mathrm{dt}, 13.8,3.1)$ & & $2.86(\mathrm{~m})$ & & $2.92(\mathrm{dd}, 13.5,5.6)$ \\
\hline $2 \mathrm{a}$ & $24.4 \mathrm{CH}_{2}$ & 1.73 (br. d, 16.3) & $20.2 \mathrm{CH}_{2}$ & $1.98(\mathrm{~m})$ & $129.4 \mathrm{CH}$ & 5.72 (overlap) \\
\hline $2 b$ & & $1.31(\mathrm{~m})$ & & $1.47(\mathrm{~m})$ & & \\
\hline $3 a$ & $19.0 \mathrm{CH}_{2}$ & $1.99(\mathrm{~d}, 16.3)$ & $19.4 \mathrm{CH}_{2}$ & $2.16(\mathrm{~m})$ & $131.8 \mathrm{CH}$ & $5.64(t, 10.8)$ \\
\hline $3 b$ & & 1.51 (overlap) & & $1.37(\mathrm{~m})$ & & \\
\hline 4 & $57.1 \mathrm{CH}$ & $2.42(\mathrm{dd}, 10.9,2.6)$ & $46.4 \mathrm{CH}$ & $2.32(\mathrm{dd}, 11.8,2.3)$ & $47.1 \mathrm{CH}$ & $3.95(\mathrm{dd}, 10.8,6.5)$ \\
\hline 5 & $205.7 \mathrm{C}$ & & $218.2 \mathrm{C}$ & & $70.5 \mathrm{CH}$ & 3.83 (br. d, 6.1) \\
\hline $6 a$ & $46.0 \mathrm{CH}_{2}$ & $2.71(\mathrm{dd}, 20.5,8.2)$ & $42.0 \mathrm{CH}_{2}$ & $2.28(\mathrm{dd}, 18.9,8.0)$ & $37.6 \mathrm{CH}_{2}$ & $1.79(\mathrm{~m})$ \\
\hline $6 \mathrm{~b}$ & & $2.39(\mathrm{~d}, 20.5)$ & & $1.93(\mathrm{~d}, 18.9)$ & & $1.64(\mathrm{dt}, 13.8,9.7)$ \\
\hline 7 & $40.2 \mathrm{CH}$ & 3.04 (br. s) & $38.2 \mathrm{CH}$ & $2.17(\mathrm{~m})$ & $40.4 \mathrm{CH}$ & $2.34(\mathrm{~m})$ \\
\hline $8 \mathrm{a}$ & $43.2 \mathrm{CH}_{2}$ & $1.80(\mathrm{~d}, 15.0)$ & $34.3 \mathrm{CH}_{2}$ & $1.39(\mathrm{~m})$ & $30.8 \mathrm{CH}_{2}$ & 2.49 (overlap) \\
\hline $8 \mathrm{~b}$ & & $1.34(\mathrm{~m})$ & & $1.39(\mathrm{~m})$ & & $2.10(\mathrm{~d}, 19.4)$ \\
\hline $9 \mathrm{a}$ & $155.8 \mathrm{C}$ & & $50.2 \mathrm{CH}_{2}$ & $3.02(\mathrm{~m})$ & $56.7 \mathrm{CH}_{2}$ & $2.67(\mathrm{~d}, 9.4)$ \\
\hline $9 b$ & & & & $2.58(\mathrm{~d}, 8.2)$ & & 2.49 (overlap) \\
\hline 10a & $177.0 \mathrm{C}$ & & $76.5 \mathrm{CH}$ & $4.68(\mathrm{t}, 4.7)$ & $20.9 \mathrm{CH}_{2}$ & $1.21(\mathrm{dt}, 11.0,7.1)$ \\
\hline $10 \mathrm{~b}$ & & & & & & $1.21(\mathrm{dt}, 11.0,7.1)$ \\
\hline $11 \mathrm{a}$ & $121.5 \mathrm{CH}$ & $6.25(\mathrm{~s})$ & $39.5 \mathrm{CH}_{2}$ & $1.73(\mathrm{~d}, 12.2)$ & $31.4 \mathrm{CH}_{2}$ & $1.71(\mathrm{~m})$ \\
\hline $11 \mathrm{~b}$ & & & & $1.50(\mathrm{~m})$ & & $1.31(\mathrm{~m})$ \\
\hline 12 & $167.3 \mathrm{C}$ & & $57.9 \mathrm{C}$ & & $57.4 \mathrm{C}$ & \\
\hline 13 & $63.1 \mathrm{C}$ & & $96.5 \mathrm{C}$ & & $201.4 \mathrm{C}$ & \\
\hline $14 \mathrm{a}$ & $44.0 \mathrm{CH}_{2}$ & $2.64(\mathrm{~d}, 16.3)$ & $29.9 \mathrm{CH}_{2}$ & $2.07(\mathrm{dd}, 15.0,5.9)$ & $124.1 \mathrm{CH}$ & 5.72 (overlap) \\
\hline $14 \mathrm{~b}$ & & $1.02(\mathrm{t}, 16.3)$ & & 1.69 (br. d, 15.0) & & \\
\hline 15 & $24.5 \mathrm{CH}$ & 1.51 (overlap) & $27.4 \mathrm{CH}$ & $2.21(\mathrm{~m})$ & $158.9 \mathrm{C}$ & \\
\hline 16 & $20.9 \mathrm{CH}_{3}$ & $0.71(\mathrm{~d}, 5.9)$ & $19.2 \mathrm{CH}_{3}$ & $1.20(\mathrm{~d}, 7.4)$ & $24.1 \mathrm{CH}_{3}$ & $1.87(\mathrm{~s})$ \\
\hline$N-\mathrm{CH}_{3}$ & & & & & $43.1 \mathrm{CH}_{3}$ & $2.29(\mathrm{~s})$ \\
\hline
\end{tabular}

${ }^{\mathrm{a}}$ Recorded in $\mathrm{CDCl}_{3}$ at $500 \mathrm{MHz}$ for ${ }^{1} \mathrm{H}$ and $125 \mathrm{MHz}$ for ${ }^{13} \mathrm{C}$; ${ }^{b}$ Recorded in $\mathrm{CDCl}_{3}$ at $600 \mathrm{MHz}$ for ${ }^{1} \mathrm{H}$ and $150 \mathrm{MHz}$ for ${ }^{13} \mathrm{C}$; ${ }^{\mathrm{c}} \mathrm{Recorded}$ in DMSO at $600 \mathrm{MHz}$ for ${ }^{1} \mathrm{H}$ and $150 \mathrm{MHz}$ for ${ }^{13} \mathrm{C}$.

C-9, and C-13 through a nitrogen atom. The above analysis indicated 1 should be a lycopodine-type alkaloid with many similarities to that of anhydrolycodoline, ${ }^{14}$ a known compound also isolated during the isolation. The obvious differences were that 1 possessed two more carbonyl groups one of which was connected to $\mathrm{C}-9\left(\delta_{\mathrm{C}} 155.8\right)$ as deduced from the HMBC correlations of $\mathrm{H}-1$ and $\mathrm{H}-11$ with $\mathrm{C}-9$. The other carbonyl group was speculated to attached at $\mathrm{C}-10$ according to the ${ }^{13} \mathrm{C}$ chemical shift and confirmed by the HMBC correlations of $\mathrm{H}-11$ to $\mathrm{C}-10$. Thus, the gross structure of obscurumine C (1) was elucidated to be 1 possessing a lycopodine-type skeleton with a scarce two adjacent ketones unit.

The relative configuration of $\mathbf{1}$ was established by ROESY experiment. In the ROESY spectrum, the correlations of H-4 with $\mathrm{H}-6 \mathrm{~b}$ and $\mathrm{H}-6 \mathrm{a}$ with $\mathrm{H}-15$ were observed which indicated the $\alpha$-orientation of H-4 and Me-16. Since the two adjacent ketone unit is scarce in Lycopodium alkaloid and to confirm the structure and the relative configuration, a X-ray crystallographic analysis of 1 (Figure 2) was carried out which unambiguously certificated the structure and the relative configurations of compound $\mathbf{1}$.

Compound 2 was obtained as colorless oil. The HREIMS analysis gave an $\mathrm{m} / \mathrm{z}$ at $261.1735\left(\left[\mathrm{M}^{+}\right]\right)$(calc. 261.1729) that established the molecular formula $\mathrm{C}_{16} \mathrm{H}_{23} \mathrm{NO}_{2}$, corresponding to six degrees of unsaturation. The ${ }^{13} \mathrm{C}$ NMR spectrum displayed 16 carbon signals due to one methyl, eight
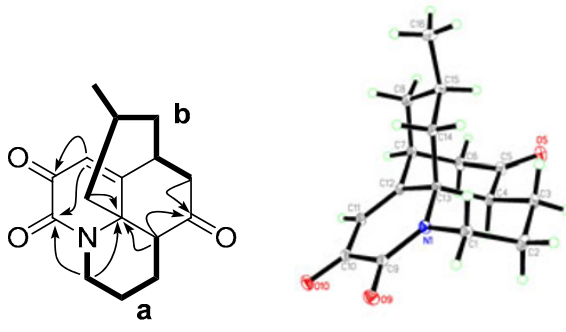

COSY:

Figure 2. Key 2D NMR correlations and X-ray structure of compound 1

methylene, four methine, and three quaternary carbons. Among them, one $s p^{3}$ quaternary carbon $\left(\delta_{\mathrm{C}} 96.5\right)$ was ascribed to the carbon $(\mathrm{C}-13)$ which bearing both an oxygen atom and a nitrogen atom and one $s p^{2}$ quaternary carbons were attributable to the ketone group $\left(\delta_{\mathrm{C}} 218.2\right)$. Partial structures a-c (C-1-C-4, C-6-C-8/C-15, and C-9-C-11) were deduced from ${ }^{1} \mathrm{H}-{ }^{1} \mathrm{H}$ COSY (Figure 3) of 2. Further detailed 2D NMR analysis suggested compound $\mathbf{2}$ was a fawcettimine-type alkaloid which was similar to that of fawcettimine. ${ }^{20}$ The obvious difference was that $\mathbf{2}$ has one oxygened methine group rather than a methylene group in fawcettimine, which was connected to $\mathrm{C}-10$ as deduced from the ${ }^{1} \mathrm{H}-{ }^{1} \mathrm{H}$ COSY

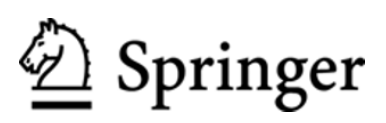


correlations of $\mathrm{H}_{2}-9 / \mathrm{H}-10 / \mathrm{H}_{2}-11$ and confirmed by the HMBC correlations of $\mathrm{H}-10$ with $\mathrm{C}-9, \mathrm{C}-11$, and $\mathrm{C}-12$. Additional, the HMBC correlation of $\mathrm{H}-10$ with $\mathrm{C}-13$ as well as the molecular formula of 2 indicated the connection of C-10 and C-13 through an oxygen atom. In ROESY spectrum, the cross peaks of $\mathrm{H}-2 \mathrm{~b} / \mathrm{H}-4$ and $\mathrm{H}-4 / \mathrm{H}-14 \mathrm{a}$ were observed, which suggested $\mathrm{H}-4$ was $\beta$-oriented. H-15 was determined to be axially oriented based on the small coupling constant between $\mathrm{H}-15$ and axial $\mathrm{H}-14 \mathrm{a}$ [dd, $\left.\left.15.0\left({ }^{3} J_{\mathrm{H} 14 \mathrm{a}-\mathrm{H} 14 \mathrm{~b}}\right), 5.9\left({ }^{3} J_{\mathrm{H} 14 \mathrm{a}-\mathrm{H} 15}\right) \mathrm{Hz}\right)\right]$ and the small coupling constant between $\mathrm{H}-15$ and equatorial $\mathrm{H}-14 \mathrm{~b}$ [br. d, $\left.15.0\left({ }^{3} J_{\mathrm{H} 14 \mathrm{a}-\mathrm{H} 14 \mathrm{~b}}\right) \mathrm{Hz}\right]$. Meanwhile, the relative configuration of $\mathrm{H}-10$ was suggested to be $\alpha$ according to the rigidity of compound 2. Therefore, the structure of $\mathbf{2}$ was established as shown in Figure 1 and named as obscurumine D.
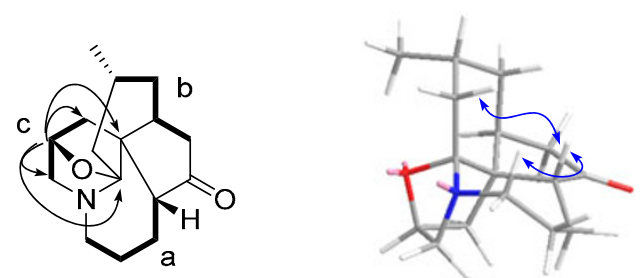

COSY: - HMBC:

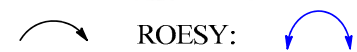

Figure 3. Key 2D NMR correlations of compound 2

Obscurumine E (3) has a molecular formula $\mathrm{C}_{17} \mathrm{H}_{25} \mathrm{NO}_{2}$ according to the HREIMS $\left[\mathrm{m} / \mathrm{z} 275.1891\right.$ ([M $\left.\left.{ }^{+}\right]\right)$, calc. 275.1885] spectrum, implying six degrees of unsaturation. The IR spectrum showed absorption bands for hydroxyl $\left(3439 \mathrm{~cm}^{-1}\right)$ and ketone $\left(1640 \mathrm{~cm}^{-1}\right)$ groups. The ${ }^{13} \mathrm{C}$ NMR and DEPT spectra revealed the existence of seventeen carbons due to three quaternary carbons, six methine groups, six methylene groups, and two methyl groups. Detailed analysis of its 1D and 2D NMR data suggested that 3 was similar to that of epilobscurinol. ${ }^{18}$ The only difference was that the double bond between $\mathrm{C}-3 / \mathrm{C}-4$ in epi-lobscurinol was shift to $\mathrm{C}-2 / \mathrm{C}-3$ as deduced from the ${ }^{1} \mathrm{H}^{-1} \mathrm{H}$ COSY correlations of $\mathrm{H}-1 / \mathrm{H}-2 / \mathrm{H}-$ $3 / \mathrm{H}-4$ and confirmed by the HMBC correlations of $\mathrm{H}-2$ with $\mathrm{C}-1$ and $\mathrm{C}-4$. In the ROESY spectrum, the correlations of $\mathrm{H}-$ $4 / \mathrm{H}-11 \mathrm{~b}$ and $\mathrm{H}-5 / \mathrm{H}-7$ were observed which suggested the relative configuration of $\mathbf{3}$ was the same as epi-lobscurinol. So, the structure of $\mathbf{3}$ was deduced and shown in Figure 1.

The new compounds obscurumine $\mathrm{C}-\mathrm{E}(\mathbf{1}-\mathbf{3})$ were tested for acetylcholine esterase (AChE) inhibitory activity. However, none of them showed obvious activity.

\section{Experimental Section}

General Experimental Procedures. Melting points were obtained on an X-4 micro melting point apparatus. Optical rotations were measured on a JASCO-20C digital polarimeter. UV spectra were recorded using a Shimadzu UV-2401A spectrophotometer. IR spectra were obtained on a Tensor 27 spectrometer with $\mathrm{KBr}$ pellets. 1D and 2D NMR spectra were performed on Bruker AM-400, DRX-500, or AVANCE III600 spectrometers with TMS as an internal standard. Mass spectra were taken on VG Auto Spec-3000 or API-QstarPulsar instruments. X-ray diffraction was performed on a Bruker APEX DUO diffractometer using graphitemonochromated Mo K $\alpha$ radiation. Column chromatography (CC) was performed using silica gel (100-200 and 200-300 mesh, Qingdao Marine Chemical Co. Ltd., Qingdao, China), MCI gel (CHP 20P, 75-150 $\mu \mathrm{m}$; Mitsubishi Chemical Co., Japan), and Sephadex LH-20 (Amersham Pharmacia Biotech, Sweden).

Plant Material. The whole plants of L. obscurum were collected from Guizhou Province, China, and identified by Professor Xiao Cheng. A voucher specimen (Lo 2011081501) was deposited with the State Key Laboratory of Phytochemistry and Plant Resources in West China, Kunming Institute of Botany, Chinese Academy of Sciences.

Extraction and Isolation. Air-dried and pulverised plants of L. obscurum were extracted three times with methanol under reflux at $50{ }^{\circ} \mathrm{C}$ and the combined extract was removed under vacuum to afford a viscous residue. The crude extract was adjusted at $\mathrm{pH} 2$ with $10 \%$ hydrochloric acid and then partitioned twice with acetic ether. Water-soluble materials, which were adjusted at $\mathrm{pH} 10$ with saturated $\mathrm{NaOH}$, were extracted three times with chloroform. The chloroform-soluble materials (479 g) were chromatographed over silica gel CC $(32 \times 120 \mathrm{~cm})$ eluting with a gradient mobile phase (petroleum ether-acetone 9:1, 8:2, 7:3, 6:4, then methanol) to give 3 major fractions, Fr.A-Fr.C. Fr.A ( $29 \mathrm{~g})$ was chromatographed on a reversed-phase preparative MPLC (MCI, $70 \times 460 \mathrm{~mm}$ ) column using step-gradient elution with a mixture of methanol/water ( $\mathrm{v} / \mathrm{v}, 70 \%$ to $100 \%$ methanol) to give three subfractions, Fr.A1-Fr.A3. Fr.A1 (13 g) was separated by repeat silica gel $\mathrm{CC}(4.6 \times 50 \mathrm{~cm})$ and recrystalization to offer $1(230 \mathrm{mg})$ as well as anhydrolycodoline $(2.1 \mathrm{~g})$. Fr.B (159 g) was subjected to a reversed-phase preparative MPLC (MCI, 70 $\times 460 \mathrm{~mm}$ ) column with a mixture solvent of methanol/water (v/v, $40 \%$ to $100 \%$ methanol) to yield five subfractions. Fr.B3 $(41 \mathrm{~g})$ was eluted on silica gel CC $(6.0 \times 60 \mathrm{~cm})$ with acetic ether-acetone (92:8) to yield a large number of lycopodine (30 $\mathrm{g})$, obscurumine B $(5.4 \mathrm{~g}),(+)$-acetylfawcettiine $(49 \mathrm{mg})$ and obscurinine $(21 \mathrm{mg})$. Fr.B4 $(1.2 \mathrm{~g})$ was purified by repeat silica gel CC $(2.6 \times 40 \mathrm{~cm})$ to afford $2(46 \mathrm{mg})$. Fr.C $(136 \mathrm{~g})$ was subjected to gradient elution on a reversed-phase preparative MPLC $(\mathrm{MCI}, 70 \times 460 \mathrm{~mm})$ column using a mixture solvent of methanol $/$ water $(\mathrm{v} / \mathrm{v}, 10 \%$ to $80 \%$ methanol) to yield three subfractions, Fr.C1-Fr.C3. Fr.C3 (4.2 g) was eluted with chloroform-methanol $(4: 1)$ on silica gel CC $(3.0 \times 40 \mathrm{~cm})$ to yield N-demethyl- $\beta$-obscurine (890 mg). Fr.C2 (8.6 g) was separated on silica gel CC $(4.0 \times 40 \mathrm{~cm})$ using petroleum ether-aceticether-diethylamine $(10: 1: 1)$ to give acetyldihydrolycopodine $(173 \mathrm{mg})$, lycoflexine $(286 \mathrm{mg})$ and another fraction which was eluted with chloroform-methanol $(2: 3)$ to yield $3(36 \mathrm{mg}$ ) and $N$-demethyl- $\alpha$-obscurine (938 mg).

Obscurumine C (1): colorless crystal; mp $195-196{ }^{\circ} \mathrm{C}$; $[\alpha]_{\mathrm{D}}^{25.8}-58.8(c 0.35, \mathrm{MeOH}) ; \mathrm{UV}(\mathrm{MeOH}): \lambda_{\max }(\log \varepsilon) 250$ (3.46), 201 (3.38) nm; IR (KBr): $v_{\max } 2964,1710,1685,1658$, 1414, 1353, 1287, $1227 \mathrm{~cm}^{-1} ;{ }^{1} \mathrm{H}$ and ${ }^{13} \mathrm{C}$ NMR data, see Table 1; ESIMS: m/z $274[\mathrm{M}+\mathrm{H}]^{+}$; HREIMS: m/z $273.1359\left[\mathrm{M}^{+}\right]$ (calc. for $\mathrm{C}_{16} \mathrm{H}_{19} \mathrm{NO}_{3} 273.1365$ ).

Obscurumine D (2): colorless oil; $[\alpha]_{\mathrm{D}}^{25.8}-126.6$ (c 0.18 , $\mathrm{MeOH})$; UV (MeOH): $\lambda_{\max }(\log \varepsilon) 204(2.48) \mathrm{nm}$; IR (KBr): $v_{\max } 2932,1737$ (ketone) 1641,1454, $1126 \mathrm{~cm}^{-1} ;{ }^{1} \mathrm{H}$ and ${ }^{13} \mathrm{C}$ 
NMR data, see Table 1; ESIMS: m/z $262[\mathrm{M}+\mathrm{H}]^{+}$; HREIMS: $\mathrm{m} / \mathrm{z} 261.1735\left[\mathrm{M}^{+}\right]$(calc. for $\mathrm{C}_{16} \mathrm{H}_{23} \mathrm{NO}_{2} 261.1729$ ).

Obscurumine E (3): colorless oil; $[\alpha]_{\mathrm{D}}^{25.8}+100.0$ (c 0.15 , $\mathrm{MeOH})$; UV (MeOH): $\lambda_{\max }(\log \varepsilon) 238$ (3.47) nm; IR (KBr): $v_{\max } 3439,1640 \mathrm{~cm}^{-1} ;{ }^{1} \mathrm{H}$ and ${ }^{13} \mathrm{C}$ NMR data, see Table 1; ESIMS: $\mathrm{m} / \mathrm{z} 276[\mathrm{M}+\mathrm{H}]^{+}$; positive ion HREIMS: $\mathrm{m} / \mathrm{z}$ $275.1891\left[\mathrm{M}^{+}\right]$(calc. for $\mathrm{C}_{17} \mathrm{H}_{25} \mathrm{NO}_{2} 275.1885$ ).

Crystal Data for Obscurumine C (1): $\mathrm{C}_{16} \mathrm{H}_{19} \mathrm{NO}_{3}, M=$ 273.32; orthorhomic, space group $P 22_{1} 2_{1} 2_{1} ; a=8.1260(8) \AA, b$ $=12.8706$ (12) $\AA, c=12.9226$ (12) $\AA, \alpha=90.00, \beta=90.00, \gamma$ $=90.00, V=1351.5(2) \AA^{3}, Z=4, \mu(\mathrm{MoK} \alpha)=0.093 \mathrm{~mm}^{-1}$, crystal dimensions $0.87 \times 0.36 \times 0.30 \mathrm{~mm}$ was used for measurement on a Bruker APEX DUO diffractometer using graphitemonochromated Mo $\mathrm{K} \alpha$ radiation. The total number of reflections measured was 9380 , of which 4335 , were observed, $I>2 \sigma(I)$. Final indices: $R_{1}=0.0599$, $\mathrm{w} R_{2}=0.1719$. Crystallographic data for the structure of $\mathbf{1}$ have been deposited in the Cambridge Crystallographic Data Centre (deposition number CCDC 908305). Copies of the data can be obtained free of charge from the CCDC via www.ccdc.cam.ac.uk.

Acetylcholinesterase Inhibition. Acetylcholinesterase (AChE) inhibitory activity of the compounds isolated was assayed by the spectrophotometric method developed by Ellman et. al. with slightly modification. ${ }^{21} S$-Acetylthiocholine iodide, $S$-butyrylthiocholine iodide,5,5'-dithio-bis-(2-nitrobenzoic) acid (DTNB, Ellman's reagent), acetylcholinesterase derived from human erythrocytes were purchased from Sigma Chemical. Compounds were dissolved in DMSO. The reaction mixture (totally $200 \mu \mathrm{L}$ ) containing phosphate buffer ( $\mathrm{pH} 8.0$ ), test compound $(50 \mu \mathrm{M})$, and acetyl cholinesterase $(0.02 \mathrm{U} / \mathrm{mL})$, was incubated for $20 \mathrm{~min}\left(30^{\circ} \mathrm{C}\right)$. Then, the reaction was initiated by the addition of $40 \mu \mathrm{L}$ of solution containing DTNB $(0.625 \mathrm{mM})$ and acetylthiocholine iodide $(0.625 \mathrm{mM})$ for AChE inhibitory activity assay, respectively. The hydrolysis of acetylthiocholine was monitored at $405 \mathrm{~nm}$ every 30 seconds for one hour. Tacrine was used as positive control with final concentration of $0.333 \mu \mathrm{M}$. All the reactions were performed in triplicate. The percentage inhibition was calculated as follows: \% inhibition $=(\mathrm{E}-\mathrm{S}) / \mathrm{E} \times 100(\mathrm{E}$ is the activity of the enzyme without test compound and $\mathrm{S}$ is the activity of enzyme with test compound).

\section{Electronic Supplementary Material}

Supplementary material is available in the online version of this article at http://dx.doi.org/ 10.1007/s13659-013-0015-x and is accessible for authorized users.

\section{Acknowledgments}

This work was financially supported by the National Basic Research Program of China (973 Program Nos. 2011CB915503 and 2009CB522303) and the National Natural Science Foundation of China (Nos. U0932602 and 90813004).

Open Access This article is distributed under the terms of the Creative Commons Attribution License which permits any use, distribution, and reproduction in any medium, provided the original author(s) and source are credited.

\section{References}

[1] Hirasawa, Y.; Kobayashi, J.; Moritaa, H. Heterocycles 2009, 77, $679-729$.

[2] Ma, X. Q.; Gang, D. R. Nat. Prod. Rep. 2004, 21, 752-772.

[3] Saha, M.; Carter, R. G. Org. Lett. 2013, 15, 736-739.

[4] Newton, J. N.; Fischer, D. F.; Sarpong, R. Angew. Chem. Int. Ed. 2013, 52, 1726-1730.

[5] Wang, X. J.; Liu, Y. B.; Li, L.; Yu, S. S.; Lv, H. N.; Ma, S. G.; Bao, X. Q.; Zhang, D.; Qu, J.; Li, Y. Org. Lett. 2012, 14, 56885691.

[6] Zhang, H. Y. Acta Pharm. Sin. 2012, 33, 1170-1175.

[7] Jiangsu New Medical College, Dictionary of Chinese Traditional Medicines (Shang-hai Science and Technology Press, Shanghai, 1977), p. 553.

[8] Morita, H.; Ishiuchi, K.; Haganuma, A.; Hoshino, T.; Obara, Y.; Nakahatab, N.; Kobayashi, J. Tetrahedron 2005, 61, 1955-1960.

[9] Hu, T.; Chandler, R. F.; Hanson, A. W. Tetrahedron Lett. 1987, 28, 5993-5996.

[10] Manske, R. H. F.; Marion, L. Can. J. Res., Sec. B: Chem. Sci. 1944, 22, 53-55.

[11] He, J.; Chen, X. Q.; Li, M. M.; Zhao, Y.; Xu, G.; Cheng, X.; Peng, L. Y.; Xie, M. J.; Zheng, Y. T,; Wang, Y. P.; Zhao, Q. S. Org. Lett. 2009, 11, 1397-1400.

[12] Dong, L. B.; Yang, J.; He, J.; Luo, H. R.; Wu, X. D.; Deng, X.; Peng, L. Y.; Cheng, X.; Zhao, Q. S. Chem. Commun. 2012, 48, 9038-9040.

[13] Perrya, G. S.; Meclean, D. B. Can. J. Res. 1956, 34, 1189-1199.

[14] Morita, H.; Hirasawa, Y.; Kobayashi, J. J. Nat. Prod. 2005, 68, $1809-1812$.

[15] Takayama, H.; Katakawa, K.; Kitajima, M.; Yamaguchi, K.; Aimi, N. Tetrahedron Lett. 2002, 43, 8307-8311.

[16] Muñoz, O. M.; Castillo, M.; Feliciano, A. S. J. Nat. Prod. 1990, $53,200-203$.

[17] Laemmerhold, K. M.; Breit, B. Angew. Chem. Int. Ed. 2010, 49, 2367-2370.

[18] Ayer, W. A.; Kasitu, G. C. Can. J. Res. 1956, 34, 1077-1086.

[19] Katakawa, K.; Kogure, N.; Kitajima, M.; Takayama, H. Helv. Chim. Acta. 2009, 92, 445-452.

[20] Takayama, H.; Katakawa, K.; Kitajima, M.; Kentaro Yamaguchib K.; Aimia, N. Tetrahedron Lett. 2002, 43, 8307-8311.

[21] Ellman, G. L.; Courtney, K. D.; Andres, V. J.; Featherstone, R. M. Biochem. Pharmacol. 1961, 7, 88-95.

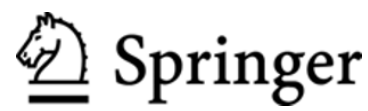

